\title{
The effects of long-acting bronchodilators on total mortality in patients with stable chronic obstructive pulmonary disease
}

\author{
Agnes Kliber ${ }^{1}$, Larry D Lynd 2,3 and Don D Sin ${ }^{* 1,3,4}$
}

\begin{abstract}
Background: Chronic obstructive pulmonary disease (COPD) is the $4^{\text {th }}$ leading cause of mortality worldwide. Longacting bronchodilators are considered first line therapies for patients with COPD but their effects on mortality are not well known. We performed a comprehensive systematic review and meta-analysis to evaluate the effects of longacting bronchodilators on total mortality in stable COPD.

Methods: Using MEDLINE, EMBASE and Cochrane Systematic Review databases, we identified high quality randomized controlled trials of tiotropium, formoterol, salmeterol, formoterol/budesonide or salmeterol/fluticasone in COPD that had a follow-up of 6 months or longer and reported on total mortality. Two reviewers independently abstracted data from the original trials and disagreements were resolved by iteration and consensus.

Results: Twenty-seven trials that included 30,495 patients were included in the review. Relative risk (RR) for total mortality was calculated for each of the study and pooled together using a random-effects model. The combination of inhaled corticosteroid (ICS) and long-acting beta-2 agonist (LABA) therapy was associated with reduced total mortality compared with placebo (RR, $0.80 ; p=0.005)$. Neither tiotropium (RR, $1.08 ; p=0.61)$ nor LABA by itself $(R R, 0.90 ; p=0.21)$ was associated with mortality.
\end{abstract}

Conclusions: A combination of ICS and LABA reduced mortality by approximately $20 \%$. Neither tiotropium nor LABA by itself modifies all-cause mortality in COPD.

\section{Introduction}

Chronic obstructive pulmonary disease (COPD) affects more than 300 million people worldwide [1]. It is currently the $4^{\text {th }}$ leading cause of mortality accounting for nearly 3 million deaths annually and is the only major cause of mortality that is increasing in both the developed and developing countries [2]. By 2020, it will become the $3^{\text {rd }}$ leading cause of death (accounting for 5 million deaths per year) and the $5^{\text {th }}$ leading causing of disability worldwide [2]. Expert guidelines recommend the use of longacting bronchodilators as first-line therapies for patients with persistent symptoms $[3,4]$. However, their effect on mortality remains controversial. A previous meta-analysis suggested that inhaled long-acting anticholinergic bronchodilators had no effect on total mortality [5]. On

* Correspondence: don.sin@hli.ubc.ca

1 Department of Medicine (Respiratory Division), University of British Columbia, 6040 lona Drive, Vancouver, V6T 2E8, Canada

Full list of author information is available at the end of the article the other hand, a secondary analysis of the UPLIFT trial suggested a mortality benefit [6]. Similarly, although the TORCH trial suggested a modest mortality benefit with inhaled corticosteroid/long-acting beta-2 agonist combination (ICS/LABA), meta-analyses suggested that they may only reduce mortality when compared to placebo [7] or ICS alone [8] but not to LABA alone [7]. However, there were several limitations to the prior meta-analyses, which may have led to some of the discordant findings. First, the prior meta-analysis on tiotropium did not include data from the recently completed UPLIFT trial. Second, prior meta-analyses did not address the effect of LABA on total mortality, making it difficult to assess whether or not LABA can be used as a reasonable comparator for ICS/LABA. Third, the findings from the ICS/ LABA on mortality are dominated by data from one trial (i.e. TORCH), raising doubts about the robustness of the results from previous meta-analyses. Fourth, and most 
importantly, many of the previous trials of ICS/LABA used a factorial design. However, none of these studies had sufficient power to assess interactions between treatments or to adjust for multiple comparisons. From a methodological perspective, it is essential that the active treatment drugs be compared against one (primary) reference group (and not to each other) unless adjustments are made for multiple comparisons [9]. To address these limitations and to determine the effects of these drugs on total mortality in COPD, we performed a systematic review and meta-analysis with and without TORCH for ICS/LABA and inclusive of UPLIFT for tiotropium. Importantly, to maintain statistical integrity, for trials that used a factorial design, we determined survival effects of the primary active treatment drug against the principal comparator group identified a priori in each of the individual studies.

\section{Methods}

\section{Data Sources and Searches}

We examined the relationship of tiotropium, a long-acting anticholinergic, as well as formoterol and salmeterol, which are long-acting beta- 2 agonists, by themselves or in combination with an inhaled corticosteroid to all-cause mortality. Using MEDLINE, EMBASE and Cochrane Systematic Review databases, we conducted a detailed literature search to identify high-quality randomized controlled trials of tiotropium, formoterol, salmeterol, formoterol/budesonide or salmeterol/fluticasone in patients with stable COPD in which total mortality was reported. We supplemented the electronic search by reviewing the bibliographies of selected articles, examining review articles on this topic and contacting experts in the field. Studies in abstract form were included only if the methods and results could be adequately analyzed.

\section{Study Selection}

We restricted the search to studies that were conducted in adults ( $>19$ years of age), had follow-up of 6 months or greater, and were published in the English language with a Jadad score of 3 or greater [10]. We restricted the duration to 6 months to ensure that patients had a reasonable window of exposure to the drugs. We excluded trials in which there were no deaths. The details of the search are provided in Additional File 1.

\section{Data Extraction and Quality Assessment}

Data were abstracted from each trial by 2 authors (A.K, D.D.S) independently using a standardized data abstraction form. Any discrepancies were resolved by iteration and consensus. The primary endpoint was total mortality (regardless of the cause). Disease specific mortality was not determined as assigning causality to deaths in COPD is problematic and fraught with errors [11]. The trials were stratified according to the study drug and to the main comparator group. For analytic purposes, the active treatment compound (i.e. tiotropium, formoterol, salmeterol or formoterol/budesonide or salmeterol/fluticasone) was compared against the main reference group. In most cases, the main reference group was placebo; however, we also included studies in which the main comparator was another active drug (e.g. tiotropium or salmeterol). Quality of the trials was assessed using the QUOROM guidelines as well as using the Jadad scale [10].

\section{Data Synthesis and Analysis}

The results were analyzed by intention-to-treat whenever possible. To maintain the statistical integrity of the original trial, for studies that used a factorial design, we determined the mortality rate of the active treatment drugs against one (primary) reference group (e.g. placebo) that were identified a priori. This mitigated the possibility of post hoc analyses. To be conservative, a DerSimonian and Laird random-effects model was used to pool the results of individual trials together. The results are reported as relative risks (RR) and 95\% confidence intervals (CI). Heterogeneity of results across individual studies was examined using a chi-square test. All analyses were conducted using RevMan version 5.0 (the Cochrane Collaboration, Oxford, England).

\section{Results}

The search results are shown in figure 1. The baseline patient characteristics of the selected studies are summarized in Table 1 . We identified 6 trials that compared salmeterol/fluticasone combination against placebo ( $\mathrm{n}=$ 2781 in active treatment vs 2487 in placebo), 4 trials that compared formoterol/budesonide against placebo $(\mathrm{n}=$ 1233 vs $n=1242$ ), 1 trial that compared salmeterol/fluticasone against tiotropium $(n=658$ vs 665$)$ and 6 trials that compared salmeterol/fluticasone against salmeterol by itself $(n=2094$ vs $n=2088)$. One trial was excluded as treatment with salmeterol/fluticasone or salmeterol alone was in addition to tiotropium, which could have led to significant drug to drug interactions [12]. The collective results of inhaled corticosteroid/long-acting beta-2 agonist combination are summarized in figure 2. In total, there were 269 deaths in the inhaled corticosteroid (ICS)/ long acting beta- 2 agonist (LABA) arm $(\mathrm{n}=6766)$ and 333 deaths in the reference group $(n=6482)$ for a relative risk of 0.80 (95\% CI, 0.69 to $0.94 ; \mathrm{p}=0.005)$ in favor of the active treatment group. The results were largely driven by data from Calverley et al, which accounted for $74 \%$ of the total weight [13]. The data, however, were robust to the exclusion of Calverley et al's study. Its exclusion resulted in a similar risk estimate in favor of ICS/LABA combination (RR, 0.73; 95\% CI, 0.54 to $0.99 ; \mathrm{p}=0.04$ ) (figure 3 ). 
Figure 1. Flow Diagram Outlining the Search Strategy

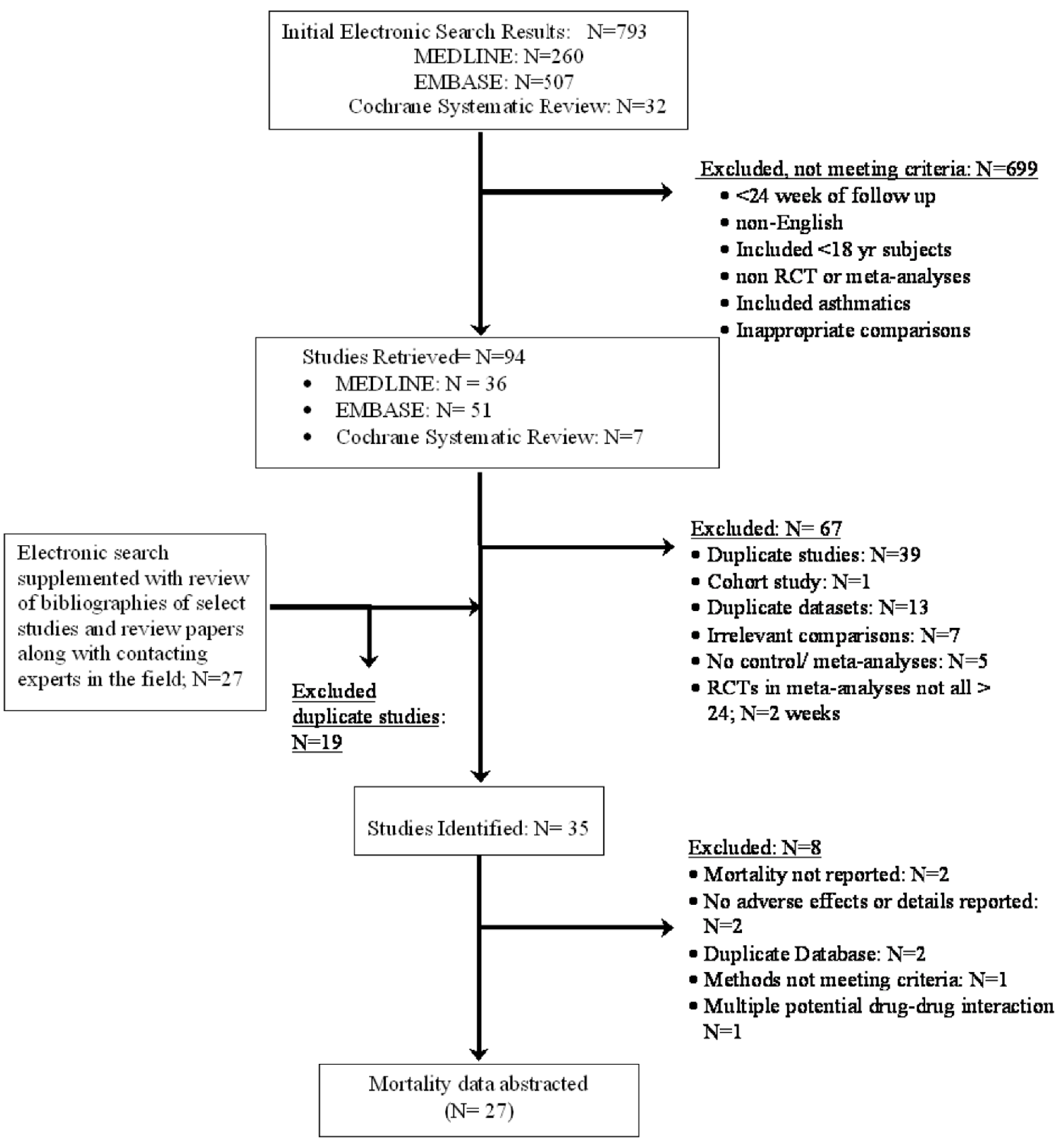

Figure 1 Flow Diagram Outlining the Search Strategy.

The comparison between ICS/LABA and placebo (excluding studies that did not use a placebo comparator) was also significant (RR, $0.83 ; 95 \% \mathrm{CI}, 0.70$ to $0.98 ; \mathrm{p}=$ 0.03; see figure 4).

We identified 5 trials that compared salmeterol against placebo. There were 222 deaths in the salmeterol group $(\mathrm{n}=2795)$ and 254 deaths in the placebo group $(\mathrm{n}=2805)$ for a relative risk of $0.88(95 \% \mathrm{CI}, 0.75$ to $1.04 ; \mathrm{p}=0.13)$ (figure 5). There were 4 trials that compared formoterol against placebo. In these studies, there were 24 deaths in the formoterol group $(\mathrm{n}=1235)$ and 19 deaths in the placebo group $(\mathrm{n}=1242)$ for a relative risk of $1.23(95 \% \mathrm{CI}$, 0.61 to $2.46 ; \mathrm{p}=0.57$ ). In total, the long-acting beta- 2 agonists by themselves did not significantly alter total mortality in COPD (RR, 0.90; $95 \% \mathrm{CI}, 0.77$ to $1.06 ; \mathrm{p}=$ $0.21)$. 
Table 1: Summary Of Clinical Trials That Were Included In This Analysis

\begin{tabular}{|c|c|c|c|c|c|c|c|c|c|c|c|}
\hline Author & $\mathbf{N}$ & Drug 1 & Drug 2 & Comparator & Follow-up & Mean Age (SD) & $\%$ Men & Mean FEV1 (SD) & $\begin{array}{l}\text { \%Current } \\
\text { Smokers }\end{array}$ & $\begin{array}{c}\text { Jadad } \\
\text { Score }\end{array}$ & Prohibited COPD Drugs \\
\hline Casaburi 2002[39] & 921 & $\mathrm{Tl}(18 \mathrm{ug}$ OD) & None & $\mathrm{PL}$ & 49 weeks & $64(9)$ & 76 & $1.02(0.44)$ & NA & 3 & LABA/other anticholinergics \\
\hline Chan 2007[40] & 913 & $\mathrm{TI}(18$ ug OD) & None & $\mathrm{PL}$ & 48 weeks & $66(9)$ & 60 & $0.97(0.38)$ & 32 & 3 & other anticholinergics, oral beta agonists \\
\hline Niewoehner 2005[41] & 1829 & TI (18 ug OD) & None & $\mathrm{PL}$ & 6 months & $68(10)$ & 99 & $1.04(0.4)$ & 30 & 3 & other anticholinergics; oral CS $>20 \mathrm{mg} / \mathrm{d}$ \\
\hline Tashkin 2008[35] & 5993 & $\mathrm{TI}(18 \mathrm{ug}$ OD) & None & $\mathrm{PL}$ & 9 months & $65(8)$ & 75 & $1.10(0.4)$ & 29 & 4 & other anticholinergics \\
\hline Tonnel 2008[42] & 554 & $\mathrm{Tl}(18 \mathrm{ug}$ OD) & None & $\mathrm{PL}$ & 6 months & $64(10)$ & 86 & $1.36(0.46)$ & 75 & 4 & other anticholinergics \\
\hline Vincken 2002[14] & 535 & $\mathrm{TI}(18 \mathrm{ug}$ OD) & None & IP (40 ug QID) & 6 months & $64(8)$ & 85 & $1.22(0.43)$ & NA & 3 & LABAs, other anticholinergics \\
\hline Brusasco 2003[43] & 1207 & $\mathrm{Tl}(18 \mathrm{ug}$ OD) & SALM (50 ug BID) & $\mathrm{PL}$ & 6 months & $64(9)$ & 76 & $1.10(0.39)$ & NA & 3 & Insufficient details provided \\
\hline$\overline{\text { Vogelmeier 2008[44] }}$ & 640 & $\mathrm{TI}$ (18 ug OD) & FORM (10 ug BID) & $\mathrm{PL}$ & 24 weeks & $63(9)$ & 78 & $1.52(0.39)$ & NA & 3 & Insufficient details provided \\
\hline Tashkin 2008[20] & 1148 & $\begin{array}{c}\text { BUD/FORM (320 } \\
\text { ug/9 ug BID) }\end{array}$ & FORM (9 ug BID) & $\mathrm{PL}$ & 6 months & $63(10)$ & 67 & $1.04(0.41)$ & 41 & 4 & All prohibited except salbutamol \\
\hline$\overline{\text { Szafranski 2003[45] }}$ & 614 & $\begin{array}{l}\text { BUD/FORM ( } 320 \\
\text { ug/9 ug BID) }\end{array}$ & FORM (9 ug BID) & $\mathrm{PL}$ & 12 months & 64 (NA) & 80 & $0.98(\mathrm{NA})$ & 35 & 3 & Only study drugs allowed \\
\hline$\overline{\text { Calverley 2003[46] }}$ & 765 & $\begin{array}{l}\text { BUD/FORM (320 } \\
\text { ug/9 ug BID) }\end{array}$ & FORM (9 ug BID) & $\mathrm{PL}$ & 12 months & 64 (NA) & 76 & $0.99(0.33)$ & 34 & 3 & $\begin{array}{c}\text { ICS, all bronchodilators except terbutaline, } \\
\text { leukotriene modifiers, }\end{array}$ \\
\hline Rennard 2009[21] & 1470 & $\begin{array}{l}\text { BUD/FORM (320 } \\
\text { ug/9 ug BID) }\end{array}$ & FORM (9 ug BID) & $\mathrm{PL}$ & 12 months & $63(9)$ & 64 & $1.01(0.43)$ & 42 & 3 & All drugs except salbutamol \\
\hline$\overline{\text { Ferguson 2008[47] }}$ & 782 & $\begin{array}{l}\text { SALM/FLU (50 } \\
\text { ug/250 ug BID) }\end{array}$ & None & $\begin{array}{l}\text { SALM (50 ug } \\
\text { BID) }\end{array}$ & 12 months & $65(9)$ & 56 & $0.94(0.36)$ & 40 & 3 & ICS, LABA, TI \\
\hline Kardos 2007[48] & 998 & $\begin{array}{l}\text { SALM/FLU (50 } \\
\text { ug/500 ug BID) }\end{array}$ & None & $\begin{array}{l}\text { SALM (50 ug } \\
\text { BID) }\end{array}$ & 44 weeks & $63(8)$ & 76 & $1.13(0.41)$ & 42 & 3 & regular oral CS, LABA and TI \\
\hline Wedzicha 2008[15] & 1323 & $\begin{array}{l}\text { SALM/FLU (50 } \\
\text { ug/500 ug BID) }\end{array}$ & None & TI 18 ug OD & 24 months & 64 (NA) & 83 & $1.12(\mathrm{NA})$ & 38 & 4 & All drugs except salbutamol \\
\hline
\end{tabular}


Table 1: Summary Of Clinical Trials That Were Included In This Analysis (Continued)

\begin{tabular}{|c|c|c|c|c|c|c|c|c|c|c|c|}
\hline Calverley 2003[49] & 1091 & $\begin{array}{l}\text { SALM/FLU (50 } \\
\text { ug/500 ug BID) }\end{array}$ & SALM (50 ug BID) & $\mathrm{PL}$ & 12 months & 64 (NA) & 73 & $1.26(0.48)$ & 52 & 5 & Oral or inhaled CS or LABAs \\
\hline SCO30002 2008 [50] & 387 & $\begin{array}{l}\text { SALM/FLU (25 } \\
\text { ug/250 ug BID) }\end{array}$ & FP (250 ug BID) & $\mathrm{PL}$ & 12 months & $65(9)$ & 82 & $1.54(\mathrm{NA})$ & NA & 3 & Not specified \\
\hline SCO100540 2006[51] & 445 & $\begin{array}{l}\text { SALM/FLU (50 } \\
\text { ug/500 ug BID) }\end{array}$ & None & $\mathrm{PL}$ & 6 months & $66(8)$ & 89 & $1.05(0.37)$ & NA & 3 & Not specified \\
\hline Mahler 2002[52] & 506 & $\begin{array}{l}\text { SALM/FLU (50 } \\
\text { ug/500 ug BID) }\end{array}$ & SALM (50 ug BID) & $\mathrm{PL}$ & 24 weeks & 62 (NA) & 64 & $1.27(\mathrm{NA})$ & 50 & 3 & Bronchodilators except salbutamol, oral CS \\
\hline Calverley 2007[13] & 4633 & $\begin{array}{l}\text { SALM/FLU (50 } \\
\text { ug/500 ug BID) }\end{array}$ & SALM (50 ug BID) & $\mathrm{PL}$ & 36 months & $65(8)$ & 76 & $1.12(0.4)$ & 43 & 4 & CS, LABA \\
\hline Zheng 2007[53] & 445 & $\begin{array}{l}\text { SALM/FLU (50 } \\
\text { ug/500 ug BID) }\end{array}$ & NA & $\mathrm{PL}$ & 24 weeks & $66(8)$ & 89 & 1.05 (NA) & 22 & 4 & ICS, LABA \\
\hline Stockley 2006[54] & 634 & SALM (50 ug BID) & NA & $\mathrm{PL}$ & 12 months & $62(9)$ & 77 & $1.30(0.5)$ & 40 & 4 & TI or LABA \\
\hline SCO30002 2008[55] & 256 & $\begin{array}{l}\text { SALM/FLU (50 } \\
\text { ug/500 ug BID) }\end{array}$ & FLU (500 ug BID) & PL & 52 weeks & 64 (NA) & 82 & $1.50(\mathrm{NA})$ & NA & 3 & Not specified \\
\hline SCO100470 2006 [56] & 1050 & $\begin{array}{l}\text { SALM/FLU (50 } \\
\text { ug/250 ug BID) }\end{array}$ & None & $\begin{array}{l}\text { SALM (50 ug } \\
\text { BID) }\end{array}$ & 6 months & $64(9)$ & 78 & $1.67(0.46)$ & NA & 3 & Not specified \\
\hline Anzueto 2009[57] & 797 & $\begin{array}{l}\text { SALM/FLU (50 } \\
\text { ug/250 ug BID) }\end{array}$ & None & $\begin{array}{l}\text { SALM (50 ug } \\
\text { BID) }\end{array}$ & 12 months & 65 (NA) & 54 & $1.17(0.51)$ & 42 & 4 & $\begin{array}{l}\text { All prohibited except salbutamol and } \\
\text { ipratropium }\end{array}$ \\
\hline SCO40041 2008 [58] & 186 & $\begin{array}{l}\text { SALM/FLU (50 } \\
\text { ug/250 ug BID) }\end{array}$ & None & $\begin{array}{l}\text { SALM (50 ug } \\
\text { BID) }\end{array}$ & 3 years & $66(9)$ & 61 & NA & NA & 3 & Not specified \\
\hline Wouters 2005 [59] & 373 & $\begin{array}{l}\text { SALM/FLU (50 } \\
\text { ug/500 ug BID) }\end{array}$ & None & $\begin{array}{l}\text { SALM (50 ug } \\
\text { BID) }\end{array}$ & 12 months & $64(8)$ & 74 & $1.41(0.48)$ & 37 & 4 & $\begin{array}{l}\text { All prohibited except salbutamol, } \\
\text { ipratropium and xanthines }\end{array}$ \\
\hline
\end{tabular}

$\mathrm{BID}$, twice daily; $\mathrm{CS}$, corticosteroids; $\mathrm{FEV}$, forced expiratory volume in one second; $\mathrm{FLU}$, fluticasone; FORM, formoterol; ICS, inhaled corticosteroids; IP, ipratropium bromide; $\mathrm{LABA}$, long acting bronchodilators, $\mathrm{N}=$ total sample size; NA, not available; OD, once daily; PL, placebo; SALM, salmeterol; SD, standard deviation; TI, tiotropium 


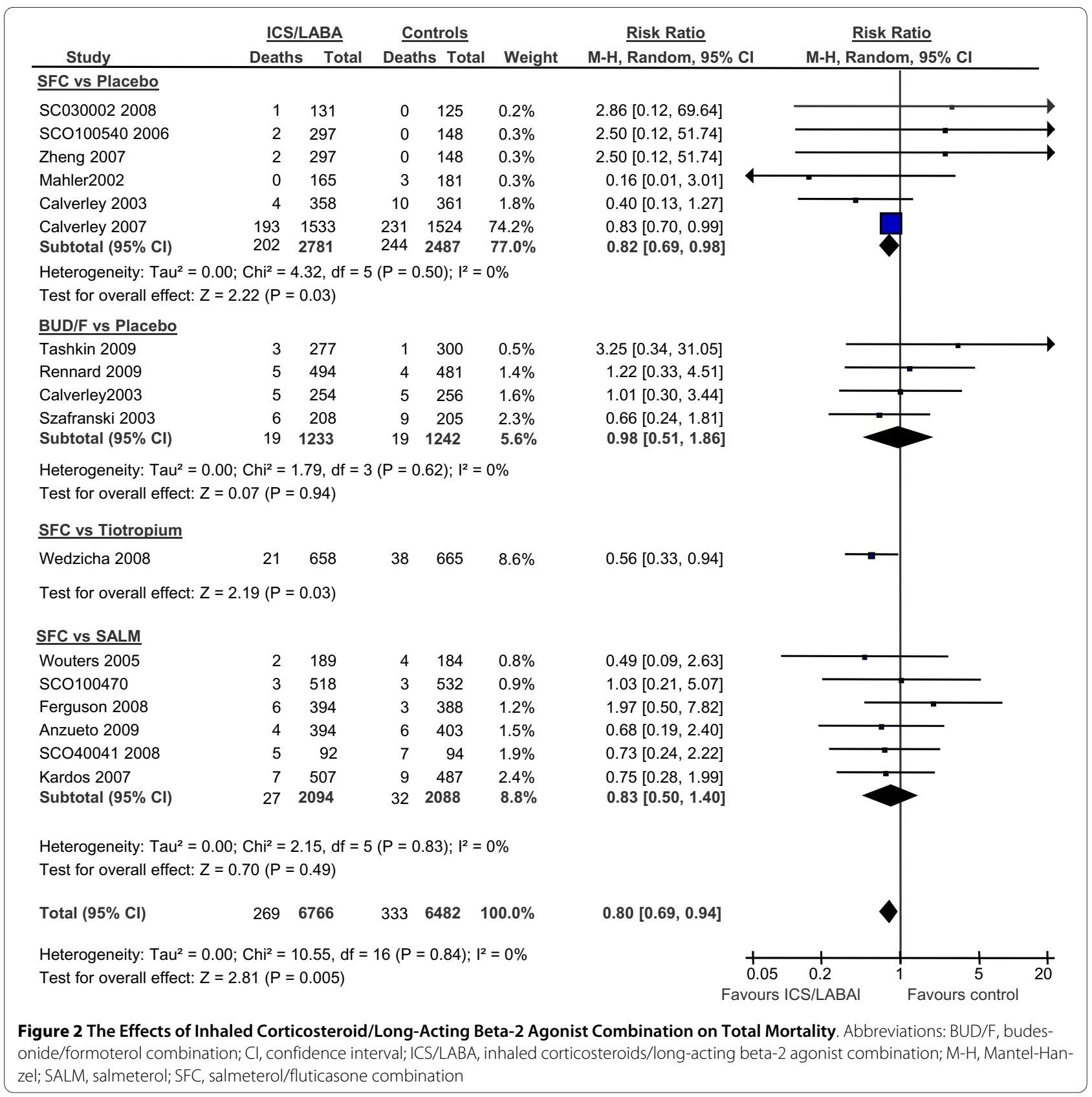

We identified 9 clinical trials that compared tiotropium against placebo but one study reported no deaths and data from one of the studies overlapped substantially with another, leaving 7 clinical trials for analysis (figure 6). In all, there were 431 deaths in the tiotropium group and 453 deaths in the placebo group for a relative risk of 0.94 ( $95 \%$ CI, 0.80 to $1.11 ; \mathrm{p}=0.46$ ). There was one study that compared tiotropium against ipratropium (RR, 1.51; 95\% CI, 0.41 to $5.50 ; \mathrm{p}=0.53$ ) [14] and one that compared tiotropium against salmeterol/fluticasone combination (RR, 1.79; 95\% CI, 1.06 to 3.02; p = 0.03) [15]. In sum, tiotropium was not associated with total mortality (RR, $1.08 ; 95 \% \mathrm{CI}, 0.79$ to $1.48 ; \mathrm{p}=0.61)$. As a sensitivity analy- sis, we excluded studies that compared tiotropium against a comparator other than placebo or ipratropium bromide and repeated the analysis. This made no material impact on the results (figure 7). Tiotropium was not associated with total mortality (RR, $0.94 ; 95 \% \mathrm{CI}, 0.83$ to 1.06; $\mathrm{p}=0.33$ ).

\section{Discussion}

The most important findings from the present metaanalysis were that 1 ) inhaled corticosteroids (ICS) in combination with a long-acting bronchodilator (LABA) were associated with a $\sim 20 \%$ reduction in total mortality; whereas LABAs or long-acting anticholinergics by them- 


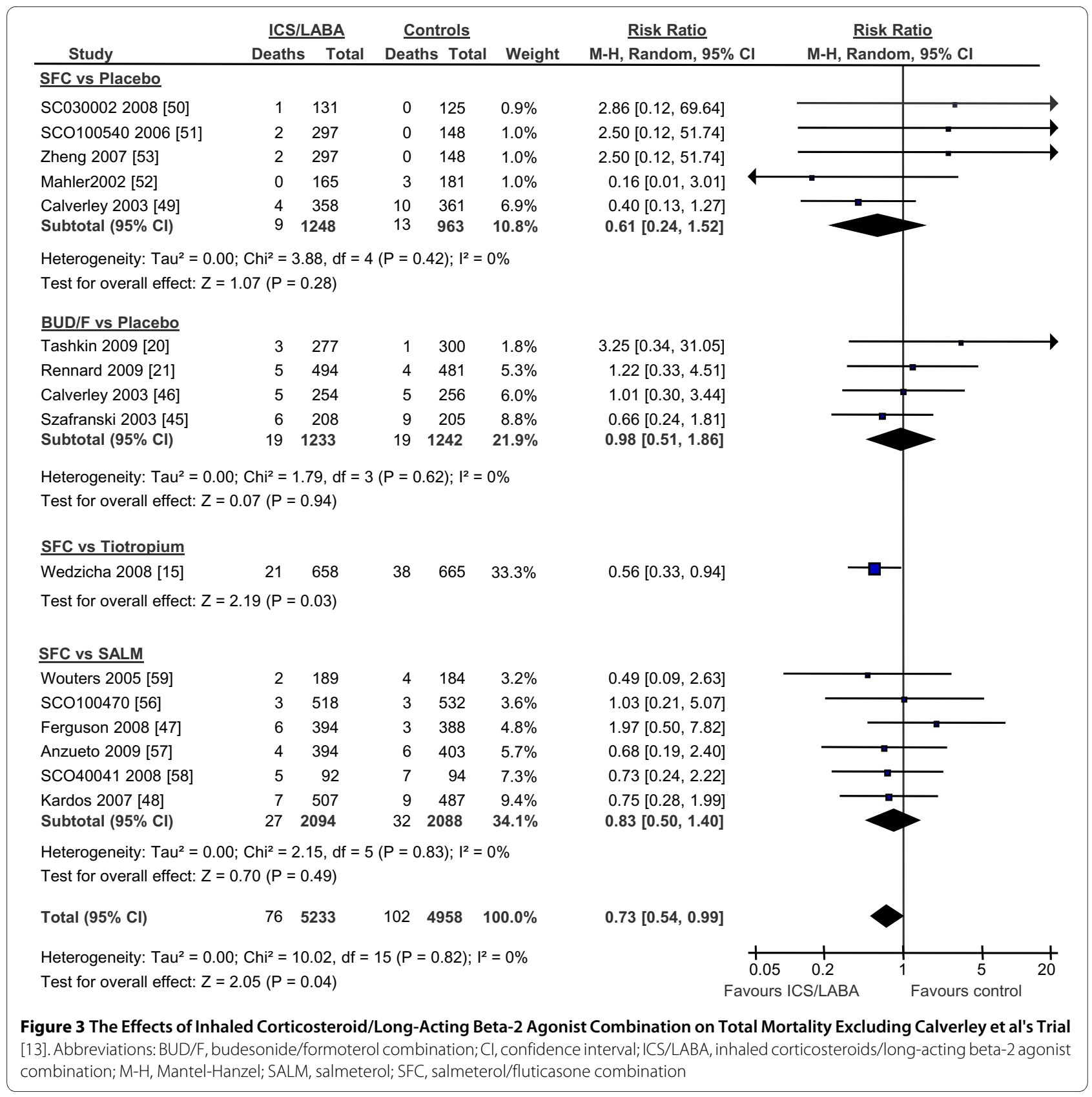

selves did not alter mortality; and 2) these data were robust to the inclusion or exclusion of the TORCH and UPLIFT trials.

These findings are largely in keeping with previous observational studies, which have shown for the most part enhanced survival with the use of ICS/LABA combinations and a lack of survival benefits of short or long acting bronchodilators by themselves [16-18]. However, our findings appear discordant with a recent meta-analysis published by Rodrigo and colleagues [19], which failed to find a significant difference in total mortality between those treated with ICS/LABA and those treated with
LABA only (though the point estimate was 0.90 in favor of ICS/LABA). However, this study excluded trials that did not have a LABA arm and failed to capture more recently published clinical trials (e.g. studies by Tashkin et $\mathrm{al}[20]$ and Rennard et al[21]). By adding these additional studies, the present meta-analysis had greater statistical power to determine the relationship of ICS/LABA combination to total mortality. More importantly, in the present meta-analysis, we compared the active treatment groups (i.e. ICS/LABA or LABA or tiotropium) against the primary reference group of the trial in order to preserve the integrity of the original trial design and avoid 


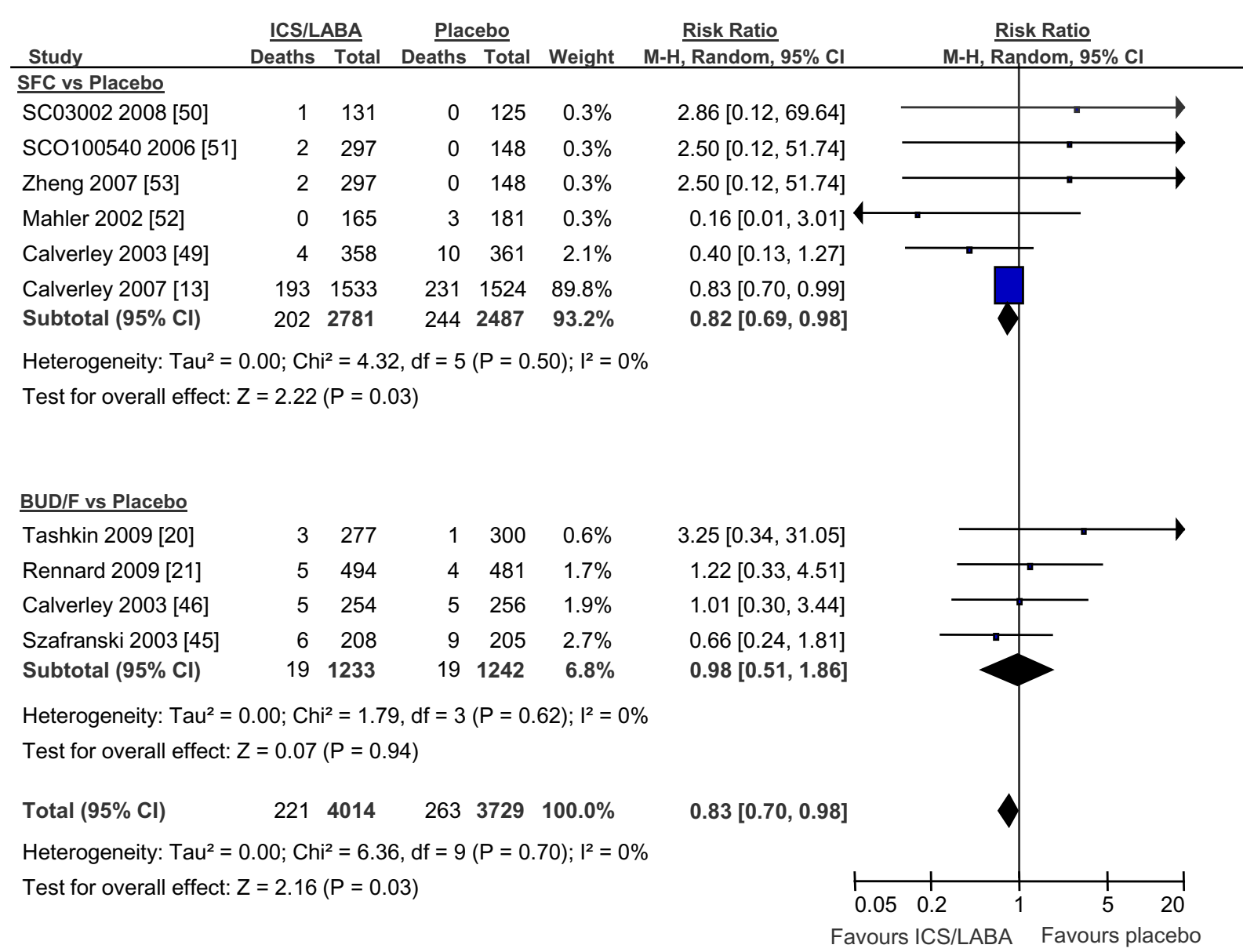

Figure 4 The Effects of Inhaled Corticosteroid/Long-Acting Beta-2 Agonist Combination on Total Mortality Using Clinical Trials That Used Placebo-Treated Patients As The Main Comparator. Abbreviations: BUD/F, budesonide/formoterol combination; $\mathrm{Cl}$, confidence interval; ICS/LABA, inhaled corticosteroids/long-acting beta-2 agonist combination; M-H, Mantel-Hanzel; SALM, salmeterol; SFC, salmeterol/fluticasone combination

the problem of multiple comparisons and post hoc analyses. Thus, for the trials that used a $2 \times 2$ factorial design, we compared the mortality effects of the active treatment arm against the main reference group of the trial (which in most cases was placebo) as the original trials did not have sufficient power to assess interactions between the groups or to correct for multiple comparisons [22].

The mechanism by which ICS/LABA combination reduces total mortality in COPD is uncertain. It is now well recognized that COPD is an inflammatory disorder, characterized by persistent lung and systemic inflammation, which intensifies with disease progression and during clinical exacerbations $[23,24]$. Once COPD develops, the inflammatory response continues to persist many years after smoking cessation [25]. Although the inflammatory process in COPD may be relatively insensitive to the actions of glucocorticoids, the addition of a long-acting beta-2 agonist to an inhaled corticosteroid appears to amplify their anti-inflammatory effects both in vitro [26] and in vivo $[27,28]$. For instance, Bourbeau and colleagues found that 3 months of therapy with salmeterol/fluticasone combination attenuated lung inflammation, as characterized by a reduction in the number of CD8 positive and CD68 positive cells in the airways of patients with severe, stable COPD; whereas fluticasone by itself had no effect [28]. Similarly, Barnes and colleagues observed a significant reduction in the expression of inflammatory biomarkers in the bronchial biopsies and sputum of COPD patients treated with salmeterol/fluticasone combination compared to those treated with placebo [27]. These data have been replicated and extended by Lapperre and colleagues, who showed that salmeterol/fluticasone therapy for 30 months reduced lung inflammation, attenuated the rate of decline in lung function, and improved bronchial responsiveness compared to salmeterol alone or placebo[29]. Inhaled corticosteroid/long acting beta- 2 agonist combination may also attenuate the systemic inflammatory response in COPD 


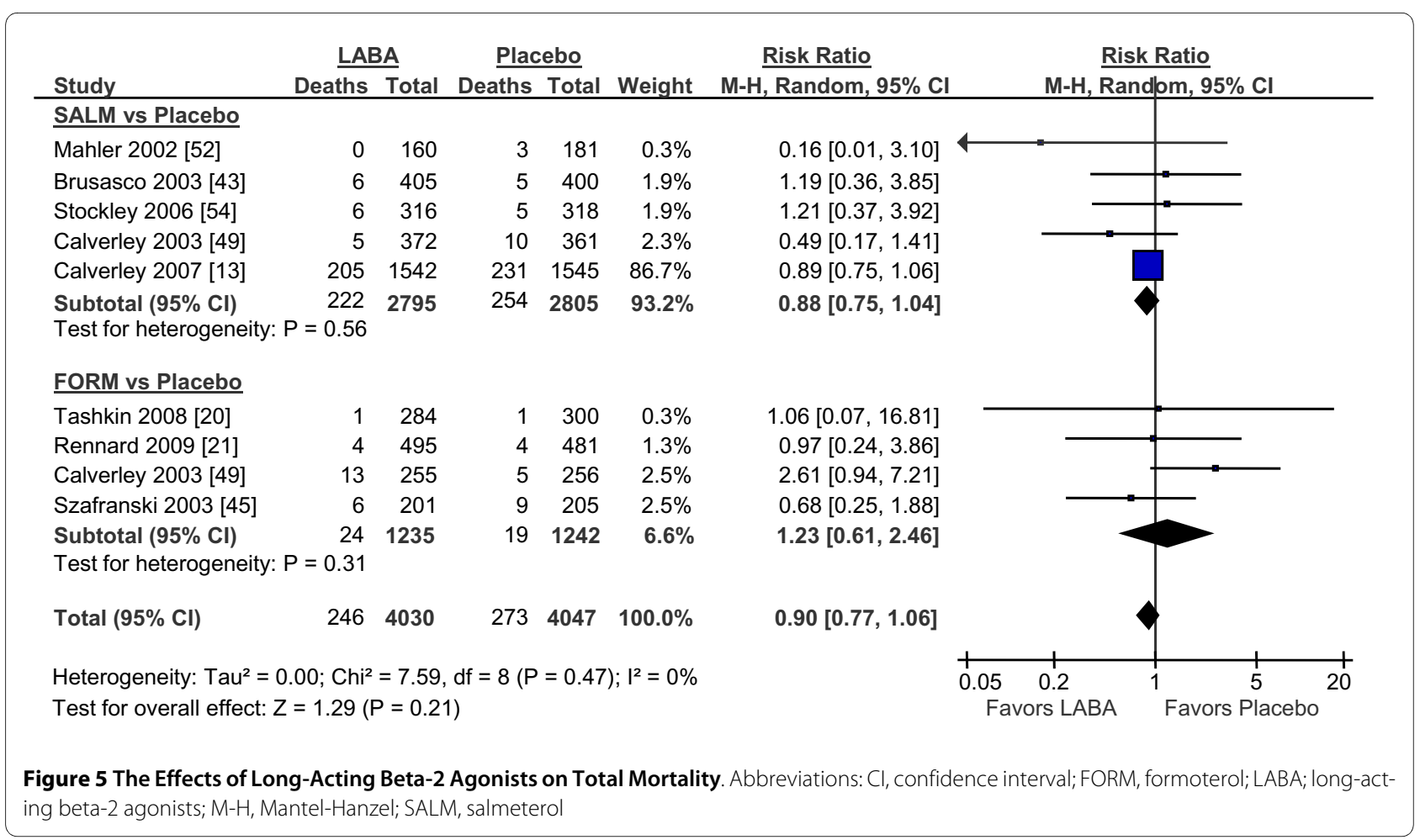

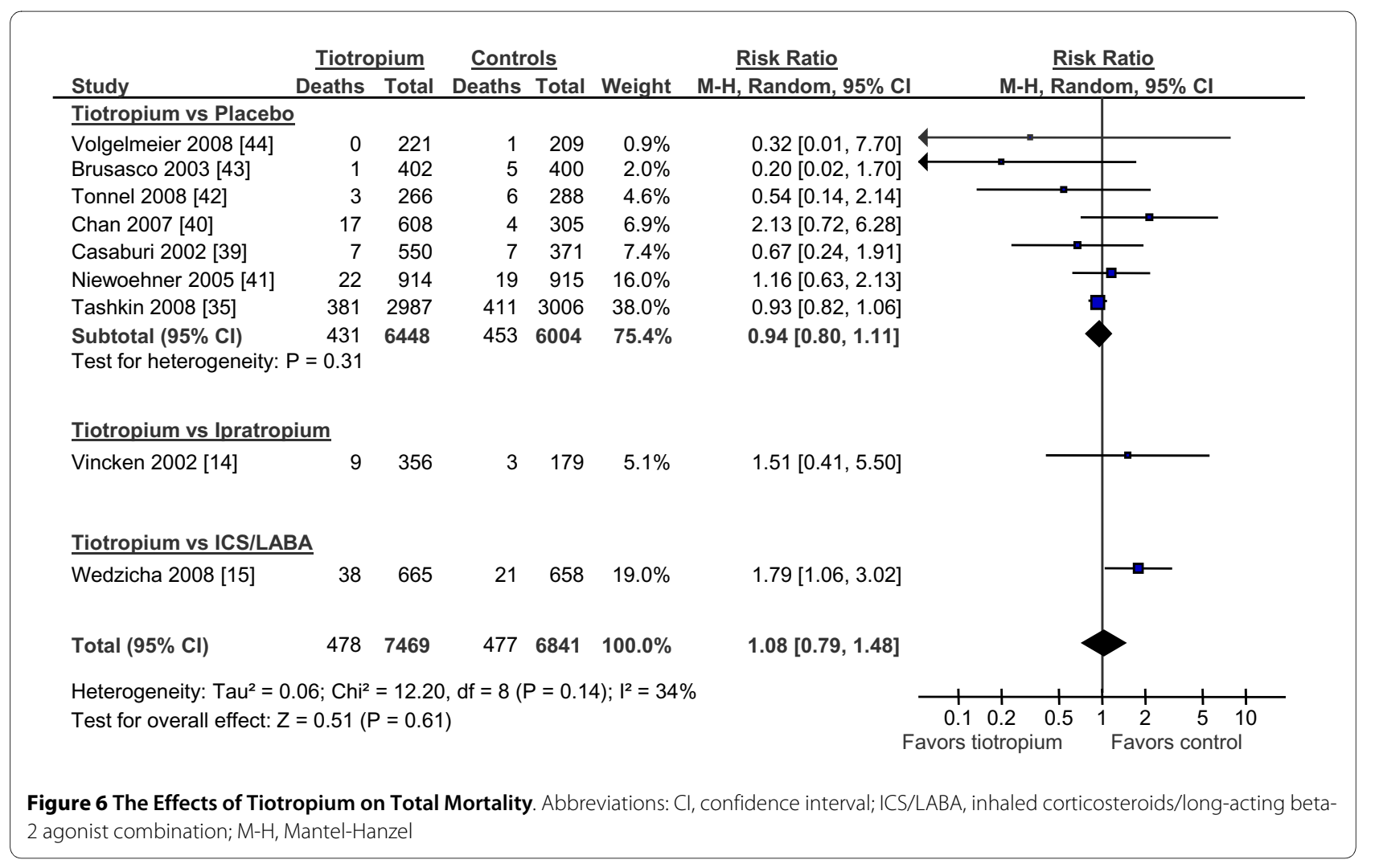




\begin{tabular}{|c|c|c|c|c|c|}
\hline \multirow[b]{2}{*}{ Study } & \multicolumn{2}{|c|}{ Tiotropium } & \multicolumn{3}{|c|}{ Placebo or Ipratropium } \\
\hline & Deaths & Total & Deaths & Total & Weight \\
\hline Volgelmeier 2008 [44] & 0 & 221 & 1 & 209 & $0.2 \%$ \\
\hline Brusasco 2003 [43] & 1 & 402 & 5 & 400 & $0.3 \%$ \\
\hline Tonnel 2008 [42] & 3 & 266 & 6 & 288 & $0.8 \%$ \\
\hline Vincken 2002 [14] & 9 & 356 & 3 & 179 & $0.9 \%$ \\
\hline Chan 2007 [40] & 17 & 608 & 4 & 305 & $1.3 \%$ \\
\hline Casaburi 2002 [39] & 7 & 550 & 7 & 371 & $1.4 \%$ \\
\hline Niewoehner 2005 [41] & 22 & 914 & 19 & 915 & $4.2 \%$ \\
\hline Tashkin 2008 [35] & 381 & 2987 & 411 & 3006 & $90.9 \%$ \\
\hline Total $(95 \% \mathrm{Cl})$ & 440 & 6804 & 456 & 6183 & $100.0 \%$ \\
\hline
\end{tabular}

Heterogeneity: $\mathrm{Tau}^{2}=0.00 ; \mathrm{Chi}^{2}=6.67, \mathrm{df}=7(\mathrm{P}=0.46) ; \mathrm{I}^{2}=0 \%$ Test for overall effect: $Z=0.97(P=0.33)$ \begin{tabular}{cc} 
Risk Ratio & \multicolumn{1}{c}{ Risk Ratio } \\
M-H, Random, $95 \%$ Cl & M-H, Random, $95 \%$ Cl \\
\hline
\end{tabular}

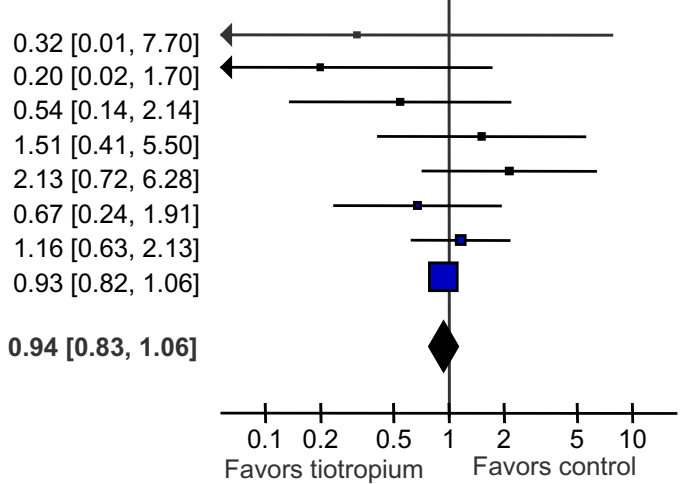

Figure 7 The Effects of Tiotropium on Total Mortality Using Clinical Trials That Used Placebo or Ipratropium Bromide As The Main Comparator. Abbreviations: $\mathrm{Cl}$, confidence interval; ICS/LABA, inhaled corticosteroids/long-acting beta-2 agonist combination; M-H, Mantel-Hanzel

[30], which is associated with morbidity and mortality [31,32].

In addition to their anti-inflammatory effects, combination therapy results in greater bronchodilation than that achieved by the individual mono-components [13]. However, the combined bronchodilatory effects of inhaled corticosteroid/beta-2 agonists is no better than that achieved with tiotropium alone in COPD [15]. Despite this, the combination therapy results in superior health status, and reduced mortality compared with tiotropium alone [15], suggesting that mechanisms other than bronchodilation and lung deflation are involved in the mortality benefits of combination therapy.

There were limitations to the present study. We did not have access to individualized data; thus, we could not adjust for potential confounders. However, to mitigate confounding, we chose large randomized controlled trials, which were of high quality (Jadad Score of 3 or greater) and had a reasonable duration of follow-up (6 months or greater), detailed accounting of all randomized patients in the study and reported excellence balance in terms of patient characteristics and clinical status between the active treatment and comparator arms. Secondly, there was some heterogeneity in the doses and drugs that were evaluated across the trials. We addressed this issue by grouping the studies together, stratified according to the drug formulation and dose and used a conservative method of pooling the data (i.e. a random effects model). Thirdly, we assessed total but not disease specific mortality. We did not evaluate disease specific mortality because assigning causality to deaths in COPD is problematic [11]. Moreover, certain drugs have been associated with increased risk of non-COPD related health events such as pneumonia [33] and stroke [34], which could have been missed by focusing on COPD-spe- cific mortality alone. Fourthly, we did not evaluate the effects of inhaled corticosteroids on total mortality because recent studies have established that these drugs do not impact on overall mortality and expert guidelines in general do not recommend inhaled corticosteroids as standalone therapies for COPD [13,33]. Fifthly, some recent trials were performed on the background of bronchodilators, inhaled corticosteroids or both, which may have diluted the possible mortality benefits of the drug in question. This may be of particular concern in the most recent tiotropium trial in which a majority of study patients were taking ICS, LABA or both at the time of recruitment [35]. Additionally, none of the studies included in this meta-analysis except for Calverley et al.' s study [13] was powered on mortality. As such, patients with complex or life-threatening co-morbidities were generally excluded from these trials, which likely reduced the statistical power of the present study and limited the generalizability of the findings to patients with multiple co-morbidities. Another important consideration was the differential drop-out rate between the active treatment and the comparator arms of the study. Collectively, the patients in the comparator arm were more likely to dropout of the trials compared with those who were assigned to active treatment arm (38\% versus $30 \%$; $<<.0001)$. Although the precise effects of differential drop-out rate are not fully known, it may have biased the results in favor of the comparator arm, as patients who drop out are generally sicker, less motivated and have poorer prognosis than those who remain in the study [36].

COPD is a worldwide epidemic affecting $\sim 10 \%$ of adults 40 years of age and older and accounting for more than 3 million deaths annually. In China alone, there will be nearly 1.5 million deaths this year from COPD [37]. Discouragingly, over the next 20 years, the worldwide 
mortality from COPD will double [38]. The totality of data from many large, randomized clinical trials indicates that the combination of inhaled corticosteroids and longacting beta- 2 agonists prolongs survival in COPD but long-acting beta- 2 agonists and tiotropium by themselves do not. The survival effect, however, is fairly modest and suggests a pressing need for additional pharmacotherapies that can reduce the overall mortality in COPD, which in less than 10 years will be the $3^{\text {rd }}$ leading cause of death worldwide.

\section{Additional material}

Additional file 1 Table S1 Detailed Electronic Search Terms Used To

Identify Relevant Clinical Trials. We used Embase", Medline" and

Cochrane Clinical Trial Registry Databases to identify relevant clinical trials for the present study. We have included detailed search terms and the

number of hits that were obtained using these search terms on their own and in combination.

\section{Abbreviations}

BUD/F: budesonide/formoterol combination; $\mathrm{Cl}$ : confidence interval; COPD: chronic obstructive pulmonary disease; ICS: inhaled corticosteroid; LABA: longacting beta-2 agonist; M-H: Mantel-Hanzel; QUOROM: quality of reporting of meta-analyses; RR: relative risk; SALM: salmeterol; SFC: salmeterol/fluticasone combination; TORCH: TOwards a Revolution in COPD Health; UPLIFT: Understanding Potential Long-Term Impacts on Function with Tiotropium

\section{Competing interests}

AK: none to declare

LDL has grant-in-aid from AstraZeneca

DDS has received honoraria for speaking engagements from GlaxoSmithKline (GSK), AstraZeneca (AZ) and Pfizer, and research funding from GSK, AZ, Wyeth Pharmaceuticals, Boehringer Ingelheim, and Pfizer over the last 3 years.

\section{Authors' contributions}

DDS conceived the idea, designed the study, acquired the primary data, performed the statistical analysis and wrote the paper.

AK acquired the primary data and wrote the paper

LDL participated in the study design, assisted on the statistical analysis, and edited the paper.

All authors have read and approved the final manuscript.

\section{Acknowledgements}

This project is supported by the Michael Smith Foundation for Health Research DDS is a Canada Research Chair in COPD and a senior scholar with the Michael Smith Foundation for Health Research (MSFHR) and LL is a New Investigator with CIHR and a scholar with the MSFHR.

\section{Author Details}

'Department of Medicine (Respiratory Division), University of British Columbia, 6040 Iona Drive, Vancouver, V6T 2E8, Canada, 2Faculty of Pharmaceutical Sciences, University of British Columbia, 6040 lona Drive, Vancouver, V6T 2E8, Canada, ${ }^{3}$ Providence Heart and Lung Institute, St. Paul's Hospital, 1081 Burrard Street, Vancouver, Canada, V6Z 1 Y6 and ${ }^{4}$ James Hogg Research Laboratories, 1081 Burrard Street, Vancouver, British Columbia, Canada, V6Z 1 Y6

Received: 11 November 2009 Accepted: 11 May 2010

Published: 11 May 2010

\section{References}

1. Murray CJ, Lopez AD: Global mortality, disability, and the contribution of risk factors: Global Burden of Disease Study. Lancet 1997, 349(9063):1436-1442

2. Murray CJ, Lopez AD: Alternative projections of mortality and disability by cause 1990-2020: Global Burden of Disease Study. Lancet 1997, 349(9064):1498-1504.
3. O'Donnell DE, Aaron S, Bourbeau J, Hernandez P, Marciniuk DD, Balter M Ford G, Gervais A, Goldstein R, Hodder R, Kaplan A, Keenan S, Lacasse Y, Maltais F, Road J, Rocker G, Sin D, Sinuff T, Voduc N: Canadian Thoracic Society recommendations for management of chronic obstructive pulmonary disease - 2007 update. Can Respir J 2007, 14(Suppl B):5B-32B.

4. Rabe KF, Hurd S, Anzueto A, Barnes PJ, Buist SA, Calverley P, Fukuchi Y, Jenkins C, Rodriguez-Roisin R, van Weel C, Zielinski J: Global strategy for the diagnosis, management, and prevention of chronic obstructive pulmonary disease: GOLD executive summary. Am J Respir Crit Care Med 2007, 176(6):532-555.

5. Barr RG, Bourbeau J, Camargo CA, Ram FS: Tiotropium for stable chronic obstructive pulmonary disease: A meta-analysis. Thorax 2006 61(10):854-862.

6. Celli B, Decramer M, Kesten S, Liu D, Mehra S, Tashkin DP: Mortality in the 4 Year Trial of Tiotropium (UPLIFT) in Patients with COPD. Am J Respir Crit Care Med 2009, 180(10):948-955

7. Nannini L, Cates CJ, Lasserson TJ, Poole P: Combined corticosteroid and long-acting beta-agonist in one inhaler versus placebo for chronic obstructive pulmonary disease. Cochrane Database Syst Rev 2007:CD003794

8. Nannini LJ, Cates CJ, Lasserson TJ, Poole P: Combined corticosteroid and long-acting beta-agonist in one inhaler versus inhaled steroids for chronic obstructive pulmonary disease. Cochrane Database Syst Rev 2007:CD006826.

9. Pocock SJ: Clinical trials with multiple outcomes: a statistical perspective on their design, analysis, and interpretation. Control Clin Trials 1997, 18(6):530-545. discussion 546-539.

10. Jadad AR, Moore RA, Carroll D, Jenkinson C, Reynolds DJ, Gavaghan DJ, McQuay HJ: Assessing the quality of reports of randomized clinical trials: is blinding necessary? Contro/ Clin Trials 1996, 17(1):1-12.

11. Janssens JP, Herrmann F, MacGee W, Michel JP: Cause of death in older patients with anatomo-pathological evidence of chronic bronchitis or emphysema: a case-control study based on autopsy findings. J Am Geriatr Soc 2001, 49(5):571-576.

12. Aaron SD, Vandemheen KL, Fergusson D, Maltais F, Bourbeau J, Goldstein R, Balter M, O'Donnell D, Mclvor A, Sharma S, Bishop G, Anthony J, Cowie R, Field S, Hirsch A, Hernandez P, Rivington R, Road J, Hoffstein V, Hodde R, Marciniuk D, McCormack D, Fox G, Cox G, Prins HB, Ford G, Bleskie D, Doucette S, Mayers I, Chapman K, Zamel N, FitzGerald M: Tiotropium in combination with placebo, salmeterol, or fluticasone-salmeterol for treatment of chronic obstructive pulmonary disease: a randomized trial. Ann Intern Med 2007, 146(8):545-555.

13. Calverley PM, Anderson JA, Celli B, Ferguson GT, Jenkins C, Jones PW, Yates JC, Vestbo J: Salmeterol and fluticasone propionate and survival in chronic obstructive pulmonary disease. N Engl J Med 2007, 356(8):775-789.

14. Vincken W, van Noord JA, Greefhorst AP, Bantje TA, Kesten S, Korducki L, Cornelissen PJ: Improved health outcomes in patients with COPD during 1 yr's treatment with tiotropium. Eur Respir J 2002, 19(2):209-216.

15. Wedzicha JA, Calverley PM, Seemungal TA, Hagan G, Ansari Z, Stockley RA: The prevention of chronic obstructive pulmonary disease exacerbations by salmeterol/fluticasone propionate or tiotropium bromide. Am J Respir Crit Care Med 2008, 177(1):19-26.

16. Lee TA, Pickard AS, Au DH, Bartle B, Weiss KB: Risk for death associated with medications for recently diagnosed chronic obstructive pulmonary disease. Ann Intern Med 2008, 149(6):380-390.

17. Lee TA, Wilke C, Joo M, Stroupe KT, Krishnan JA, Schumock GT, Pickard AS: Outcomes associated with tiotropium use in patients with chronic obstructive pulmonary disease. Arch Intern Med 2009, 169(15):1403-1410.

18. Soriano JB, Kiri VA, Pride NB, Vestbo J: Inhaled corticosteroids with/ without long-acting beta-agonists reduce the risk of rehospitalization and death in COPD patients. Am J Respir Med 2003, 2(1):67-74

19. Rodrigo GJ, Castro-Rodriguez JA, Plaza V: Safety and efficacy of combined long-acting beta-agonists and inhaled corticosteroids vs long-acting beta-agonists monotherapy for stable COPD: a systematic review. Chest 2009, 136(4):1029-1038.

20. Tashkin DP, Rennard SI, Martin P, Ramachandran S, Martin UJ, Silkoff PE, Goldman M: Efficacy and safety of budesonide and formoterol in one pressurized metered-dose inhaler in patients with moderate to very 
severe chronic obstructive pulmonary disease: results of a 6-month randomized clinical trial. Drugs 2008, 68(14):1975-2000.

21. Rennard SI, Tashkin DP, McElhattan J, Goldman M, Ramachandran S, Martin UJ, Silkoff PE: Efficacy and tolerability of budesonide/formoterol in one hydrofluoroalkane pressurized metered-dose inhaler in patients with chronic obstructive pulmonary disease: results from a 1-year randomized controlled clinical trial. Drugs 2009, 69(5):549-565.

22. Keene ON, Vestbo J, Anderson JA, Calverley PM, Celli B, Ferguson GT, Jenkins $C$, Jones PW: Methods for therapeutic trials in COPD: lessons from the TORCH trial. Eur Respir J 2009, 34(5):1018-1023.

23. Hogg JC, Chu F, Utokaparch S, Woods R, Elliott WM, Buzatu L, Cherniack RM, Rogers RM, Sciurba FC, Coxson HO, Paré PD: The nature of smallairway obstruction in chronic obstructive pulmonary disease. NEng/J Med 2004, 350(26):2645-2653.

24. Niewoehner DE, Kleinerman J, Rice DB: Pathologic changes in the peripheral airways of young cigarette smokers. N Eng/ J Med 1974 291(15):755-758.

25. Lapperre TS, Postma DS, Gosman MM, Snoeck-Stroband JB, ten Hacken NH, Hiemstra PS, Timens W, Sterk PJ, Mauad T: Relation between duration of smoking cessation and bronchial inflammation in COPD. Thorax 2006, 61(2):115-121.

26. Usmani OS, Ito K, Maneechotesuwan K, Ito M, Johnson M, Barnes PJ, Adcock IM: Glucocorticoid receptor nuclear translocation in airway cells after inhaled combination therapy. Am J Respir Crit Care Med 2005, 172(6):704-712

27. Barnes NC, Qiu YS, Pavord ID, Parker D, Davis PA, Zhu J, Johnson M, Thomson NC, Jeffery PK: Antiinflammatory effects of salmeterol/ fluticasone propionate in chronic obstructive lung disease. Am J Respir Crit Care Med 2006, 173(7):736-743.

28. Bourbeau J, Christodoulopoulos P, Maltais F, Yamauchi Y, Olivenstein R, Hamid Q: Effect of salmeterol/fluticasone propionate on airway inflammation in COPD: a randomised controlled trial. Thorax 2007, 62(11):938-943

29. Lapperre TS, Snoeck-Stroband JB, Gosman MM, Jansen DF, van Schadewijk A, Thiadens HA, Vonk JM, Boezen HM, Ten Hacken NH, Sont JK, Rabe KF, Kerstjens HA, Hiemstra PS, Timens W, Postma DS, Sterk PJ: Effect of fluticasone with and without salmeterol on pulmonary outcomes in chronic obstructive pulmonary disease: a randomized trial. Ann Intern Med 2009, 151(8):517-527.

30. Sin DD, Man SF, Marciniuk DD, Ford G, FitzGerald M, Wong E, York E, Mainra RR, Ramesh W, Melenka LS, Wilde E, Cowie RL, Williams D, Gan WQ, Rousseau R: The effects of fluticasone with or without salmeterol on systemic biomarkers of inflammation in chronic obstructive pulmonary disease. Am J Respir Crit Care Med 2008, 177(11):1207-1214.

31. Man SF, Xing L, Connett JE, Anthonisen NR, Wise RA, Tashkin DP, Zhang X, Vessey R, Walker TG, Celli BR, Sin DD: Circulating fibronectin to C-reactive protein ratio and mortality: a biomarker in COPD? Eur Respir J 2008, 32(6):1451-1457.

32. Pinto-Plata V, Toso J, Lee K, Park D, Bilello J, Mullerova H, De Souza MM, Vessey R, Celli B: Profiling serum biomarkers in patients with COPD: associations with clinical parameters. Thorax 2007, 62(7):595-601.

33. Drummond MB, Dasenbrook EC, Pitz MW, Murphy DJ, Fan E: Inhaled corticosteroids in patients with stable chronic obstructive pulmonary disease: a systematic review and meta-analysis. JAMA 2008, 300(20):2407-2416.

34. Singh S, Loke YK, Furberg CD: Inhaled anticholinergics and risk of major adverse cardiovascular events in patients with chronic obstructive pulmonary disease: a systematic review and meta-analysis. JAMA 2008, 300(12):1439-1450.

35. Tashkin DP, Celli B, Senn S, Burkhart D, Kesten S, Menjoge S, Decramer M: A 4-year trial of tiotropium in chronic obstructive pulmonary disease. NEngl J Med 2008, 359(15):1543-1554.

36. Calverley PM, Spencer S, Willits L, Burge PS, Jones PW: Withdrawal from treatment as an outcome in the ISOLDE study of COPD. Chest 2003, 124(4):1350-1356.

37. Lin HH, Murray M, Cohen T, Colijn C, Ezzati M: Effects of smoking and solid-fuel use on COPD, lung cancer, and tuberculosis in China: a timebased, multiple risk factor, modelling study. Lancet 2008, 372(9648):1473-1483.

38. Mathers $C D$, Loncar D: Projections of global mortality and burden of disease from 2002 to 2030. PLoS Med 2006, 3(11):e442.
39. Casaburi R, Mahler DA, Jones PW, Wanner A, San PG, ZuWallack RL, Menjoge SS, Serby CW, Witek T Jr: A long-term evaluation of once-daily inhaled tiotropium in chronic obstructive pulmonary disease. Eur Respir J 2002, 19(2):217-224.

40. Chan CK, Maltais F, Sigouin C, Haddon JM, Ford GT: A randomized controlled trial to assess the efficacy of tiotropium in Canadian patients with chronic obstructive pulmonary disease. Can Respir J 2007, 14(8):465-472.

41. Niewoehner DE, Rice K, Cote C, Paulson D, Cooper JA Jr, Korducki L, Cassino C, Kesten S: Prevention of exacerbations of chronic obstructive pulmonary disease with tiotropium, a once-daily inhaled anticholinergic bronchodilator: a randomized trial. Ann Intern Med 2005, 143(5):317-326.

42. Tonnel AB, Perez T, Grosbois JM, Verkindre C, Bravo ML, Brun M: Effect of tiotropium on health-related quality of life as a primary efficacy endpoint in COPD. Int J Chron Obstruct Pulmon Dis 2008, 3(2):301-310.

43. Brusasco V, Hodder R, Miravitlles M, Korducki L, Towse L, Kesten S: Health outcomes following treatment for six months with once daily tiotropium compared with twice daily salmeterol in patients with COPD. Thorax 2003, 58(5):399-404.

44. Vogelmeier C, Kardos P, Harari S, Gans SJ, Stenglein S, Thirlwell J: Formoterol mono- and combination therapy with tiotropium in patients with COPD: a 6-month study. Respir Med 2008, 102(11):1511-1520

45. Szafranski W, Cukier A, Ramirez A, Menga G, Sansores R, Nahabedian S, Peterson $\mathrm{S}$, Olsson $\mathrm{H}$ : Efficacy and safety of budesonide/formoterol in the management of chronic obstructive pulmonary disease. Eur Respir J 2003, 21(1):74-81.

46. Calverley PM, Boonsawat W, Cseke Z, Zhong N, Peterson S, Olsson H: Maintenance therapy with budesonide and formoterol in chronic obstructive pulmonary disease. Eur Respir J 2003, 22(6):912-919.

47. Ferguson GT, Anzueto A, Fei R, Emmett A, Knobil K, Kalberg C: Effect of fluticasone propionate/salmeterol (250/50 microg) or salmeterol (50 microg) on COPD exacerbations. Respir Med 2008, 102(8):1099-1108.

48. Kardos P, Wencker M, Glaab T, Vogelmeier C: Impact of salmeterol/ fluticasone propionate versus salmeterol on exacerbations in severe chronic obstructive pulmonary disease. Am J Respir Crit Care Med 2007 175(2):144-149.

49. Calverley P, Pauwels R, Vestbo J, Jones P, Pride N, Gulsvik A, Anderson J, Maden C: Combined salmeterol and fluticasone in the treatment of chronic obstructive pulmonary disease: a randomised controlled trial. Lancet 2003, 361(9356):449-456.

50. GlaxoSmithKline: SCO30002 Trial. [http://www.gskclinicalstudyregister.com/

51. GlaxoSmithKline: SCO100540 Trial. [http://www.gskclinicalstudyregister.com/

52. Mahler DA, Wire P, Horstman D, Chang CN, Yates J, Fischer T, Shah T: Effectiveness of fluticasone propionate and salmeterol combination delivered via the Diskus device in the treatment of chronic obstructive pulmonary disease. Am J Respir Crit Care Med 2002, 166(8):1084-1091.

53. Zheng JP, Yang L, Wu YM, Chen P, Wen ZG, Huang WJ, Shi Y, Wang CZ, Huang SG, Sun TY, Wang GF, Xiong SD, Zhong NS: The efficacy and safety of combination salmeterol (50 microg)/fluticasone propionate (500 microg) inhalation twice daily via accuhaler in Chinese patients with COPD. Chest 2007, 132(6):1756-1763.

54. Stockley RA, Chopra N, Rice L: Addition of salmeterol to existing treatment in patients with COPD: a 12 month study. Thorax 2006 61(2):122-128

55. GlaxoSmithKline: A Multicentre, Randomised, Double-Blind, Parallel Group, Placebo-Controlled Study to Compare the Efficacy and Safety of Inhaled Salmeterol/Fluticasone Propionate Combination Product $25 / 250 \mu \mathrm{g}$ Two Puffs Bd and Fluticasone Propionate $250 \mu \mathrm{g}$ Two Puffs Bd Alone, All Administered Via Metered Dose Inhalers (MDI), in the Treatment of Subjects with Chronic Obstructive Pulmonary Disease (COPD) for 52 Weeks. [http://www.gsk-clinicalstudyregister.com/

56. GlaxoSmithKline: SCO100470 Trial. [http://www.gskclinicalstudyregister.com/

57. Anzueto A, Ferguson GT, Feldman G, Chinsky K, Seibert A, Emmett A, Knobil K, O'Dell D, Kalberg C, Crater G: Effect of fluticasone propionate/ salmeterol (250/50) on COPD exacerbations and impact on patient outcomes. COPD 2009, 6(5):320-329. 
58. GlaxoSmithKline: SCO40041 Trial. [http://www.gskclinicalstudyregister.com/].

59. Wouters EF, Postma DS, Fokkens B, Hop WC, Prins J, Kuipers AF, Pasma HR, Hensing CA, Creutzberg EC: Withdrawal of fluticasone propionate from combined salmeterol/fluticasone treatment in patients with COPD causes immediate and sustained disease deterioration: a randomised controlled trial. Thorax 2005, 60(6):480-487.

doi: $10.1186 / 1465-9921-11-56$

Cite this article as: Kliber et al., The effects of long-acting bronchodilators on total mortality in patients with stable chronic obstructive pulmonary disease Respiratory Research 2010, 11:56

Submit your next manuscript to BioMed Central and take full advantage of:

- Convenient online submission

- Thorough peer review

- No space constraints or color figure charges

- Immediate publication on acceptance

- Inclusion in PubMed, CAS, Scopus and Google Scholar

- Research which is freely available for redistribution

Submit your manuscript at www.biomedcentral.com/submit 